\title{
Distance Education Experiences of Nurse Academician During COVID-19 Pandemic in Turkey: A Phenomenological Approach
}

\author{
Türkiye'deki Hemşire Akademisyenlerin COVID-19 Pandemi Sürecinde \\ Uzaktan Eğitime Geçiş Deneyimleri: Fenomonoloji Bir Yaklaşım
}

\section{Alev YILDIRIM KESKIN, Sibel ŞENTÜRK}

\begin{abstract}
The purpose of the study was to explore the distance education experiences of Turkish nurse academicians during the COVID-19 pandemic. The experiences of nurse academicians about distance education were discussed using a phenomenological approach. The data were gathered through semi-structured interview forms and in the online setting from 18 nurse academicians. To analyze the data; Colaizzi's phenomenological method was employed. As a result of the coding conducted, five themes were established. Distance education experiences of nurse academicians during the COVID-19 epidemic are discussed under the headings of " 1 ) difficulties encountered;2) distance education achievements; 3) coping methods; 4) examination system; 5) views about the future". Although nurse academicians underwent some difficulties caused by distance education during the COVID-19 pandemic, it was understood that they gained achievements, too. It was thought that results would guide academicians and educational institutions that would provide distance education and would help them take necessary measures against possible difficulties.
\end{abstract}

Keywords: COVID-19, Distance education, Nurse academician, Phenomenological approach

\section{ÖZ}

Çalışmanın amacı, COVID-19 salgını sırasında Türk hemşire akademisyenlerin uzaktan eğitim deneyimlerini incelemektir. Hemşire akademisyenlerin uzaktan eğitime ilişkin deneyimleri fenomenolojik yaklaşımla tartışılmıştır. Veriler yarı yapılandırılmış görüşme formları aracilığıyla ve çevrimiçi ortamda 18 hemşire akademisyenden toplanmıştır. Verileri analiz etmek için; Colaizzi'nin fenomenolojik yöntemi kullanılmıştır. Yapılan kodlama sonucunda beş tema oluşturulmuştur. Hemşire akademisyenlerin COVID-19 salgını sırasında uzaktan eğitim deneyimleri "1) karşılaşılan zorluklar; 2) uzaktan eğitim başarıları; 3) başa çıkma yöntemleri; 4) sınav sistemi; 5) gelecekle ilgili görüşler” başlıkları altında ele alınmıştır. Hemşire akademisyenlerin, COVID-19 salgını sürecinde uzaktan eğitimin neden olduğu bazı zorluklar yaşamalarına rağmen kazanımlarda elde ettikleri belirlenmiştir. Sonuçların, uzaktan eğitime geçen akademisyenlere ve eğitim kurumlarına yol göstereceği ve yaşanabilecek sıkıntılara yönelik gerekli önlemleri almalarına yardımcı olacağı düşünülmektedir.

Anahtar Sözcükler: COVID-19, Uzaktan eğitim, Hemşire akademisyen, Fenomenolojik yaklaşım

Yıldırım Keskin A., \& Şentürk S.,(2021). Distance education experiences of nurse academician during COVID-19 pandemic in Turkey: A phenomenological approach. Journal of Higher Education and Science/Yükseköğretim ve Bilim Dergisi, 11(2), 303-312. https://doi.org/10.5961/jhes.2021.450

\section{Alev YILDIRIM KESKIN (®)}

ORCID ID: 0000-0003-0981-5364

Selcuk University, Aksehir Kadir Yallagoz Health School, Department of Nursing, Aksehir-Konya, Turkey Selçuk Üniversitesi, Akşehir Kadir Yallagöz Sağlık Yüksekokulu, Hemşirelik Bölümü, Akşehir-Konya, Türkiye alevyildirim@selcuk.edu.tr

Sibel ŞENTÜRK

ORCID ID: 0000-0002-5634-174X

Burdur Mehmet Akif Ersoy University, Bucak Health School, Department of Nursing, Bucak-Burdur, Turkey Burdur Mehmet Akif Ersoy Üniversitesi, Bucak Sağlık Yüksekokulu, Hemşirelik Bölümü, Bucak-Burdur, Türkiye 


\section{INTRODUCTION}

Coronavirus (COVID-19) disease that was first identified in Wuhan City-Hubei Province, China at the end of 2019 causes mainly respiratory system diseases as well as gastrointestinal, hepatic, and neurologic diseases (Huang et al., 2020; Lu, Stratton, \& Tang, 2020; An, Song, Lian, \& Wang, 2020). The first case in Turkey of COVID-19 outbreak, which spread globally, was detected on the $10^{\text {th }}$ of March, 2020. According to the data and findings obtained, since World Health Organization (WHO) announced that the disease was a global pandemic on the $11^{\text {th }}$ of March, 2020; there have been 182.101.209 COVID-19 cases and 3.950 .876 people have died from the disease in the world as of the date of the $2^{\text {nd }}$ of July, 2021 (WHO, 2021). According to the figures of the Turkish Ministry of Health (TMH) that announced on the $2^{\text {nd }}$ of July, 2021; the number of cases in Turkey was 5.430 .940 and the number of patients who died from the disease was 49.774 (TMH, 2021).

During the COVID-19 outbreak, which affected globally; such restrictions imposed as lockdown, quarantine, social distancing, travel ban, the shutdown of institutions and workplaces, flexible shifts, distance education, and work at home have changed people's lifestyles and habits (Aslan, 2020; Serçemeli \& Kurnaz, 2020; Akça \& Tepe Küçükoğlu, 2020). During this period; one of the most hit fields is education (Aslan, 2020; Serçemeli \& Kurnaz, 2020). When the studies have done are reviewed, it is noted that the first change in education is to close schools, discontinue formal education, and launch distance education programs during the COVID-19 pandemic as seen during other pandemics (UNICEF, 2020; Wang, Cheng, Yue, \& McAleer, 2020; Viner et al., 2020; Sahu, 2020; Aslan, 2020; Serçemeli \& Kurnaz, 2020). Thus, courses were taught, and examinations were held on digital platforms in many countries (Dockery \& Bawa, 2020; Telli \& Altun, 2020). As for Turkey; The Council of Higher Education (CHE) made an announcement that education would be suspended for three weeks as of the date of the $16^{\text {th }}$ of March, 2020 (CHE, 2020a). Since the COVID-19 pandemic period was unclear, on the $26^{\text {th }}$ of March, 2020 HEC announced and communicated that face-to-face education would not be held during the spring semester of the 2019-2020 academic year and initiated distance education in Turkey (CHE, 2020b). However, because the outbreak still continued and the number of cases increased; it was planned that all the theoretical courses would be provided through distance learning while applied courses (such as medical faculties, faculties of dentistry, nursing schools, veterinary school) would be postponed if possible. If it cannot be postponed, it is planned to teach through distance learning using activities like simulations, projects, case analysis during the fall semester of 2020-2021 academic year (CHE, 2020c). Even though there were universities equipped with distance education infrastructure; teaching in distance education was seen for the first time for health schools and departments with applied courses (Serçemeli \& Kurnaz, 2020). During COVID-19 pandemic period, nursing education and other health fields were negatively affected. Due to this pandemic, both nurse academicians and students started distance education in the midst of academic year and encountered numerous difficulties. Some of these difficulties were poor distance education materials offered by universities and insufficient educational infrastructure, students' lacking technological devices for distance education, and bad network connection due to locations. Besides, nursing students could not perform face-to- face clinical practices with patients. To eliminate these drawbacks created by COVID-19; academicians who provided health education quickly prepared their curriculum and transformed it into an online format. They started clinical practices, examinations, academic assignments, case studies with small student groups in a virtual environment, and online settings. The transition from school to home resulted in isolation among academicians and students. This has caused them to spend more time on social media, to use e-mails more, and have ineffective communication and poor internet access (Alea-Aris, Fabrea-Frosyl, Roldan-Artur, \& Farooqi, 2020; Kissler, Tedijanto, Goldstein, Grad, \& Lipsitch, 2020; Honey-Roses et al., 2020).

In times of the COVID-19 pandemic; nurse academicians continued their duties through distance education. However, it is important to investigate the advantages and disadvantages of distance education, achievements that they learned from their experiences, and relevant restrictions that they felt in order to evaluate and to improve scientific activities. Considering the literature; there were no studies that discussed nurse academicians' distance education process in a phenomenological approach. In order not to get caught unprepared in times of epidemics and natural disasters; we are of the opinion that the study results will be making contributions to the literature by designing distance education pools. Thus, nurse academicians will help them not experience difficulties during these times and thus, gaps in distance education will be closed. The purpose of the study was to explore the distance education experiences of Turkish nurse academicians during the COVID-19 pandemic.

\section{MATERIAL and METHODS}

\section{Study Design}

The research was planned as a phenomenological qualitative study.

\section{Setting and Sample}

This study has established the universe of the COVID-19 distance education that nurse academicians in various regions of Turkey in the process of a pandemic. Purposeful and snowball sampling methods were applied to the study group. The characteristics of the to be nurse academicians included in the study were defined in purposeful sampling. The sample consisted of 18 nurse academicians who (1) worked as academicians for at least 1 year during the study period, (2) provided distance education during the study period, (3) agreed to participate in the study. Including snowball sampling in the study sample; the sample number of the study was increased by including one participant in the study through an interview and the participant to include the other participant/participants in the study. No rule has been determined regarding the sample size. In qualitative studies with in-depth interviews, the sample size is 
5-25. When the answers given by the participants of the study to the study questions started to be similar; It is known that the study has reached data saturation and the data collection process has been stopped Joseph (2007). Therefore, the study was terminated after 18 individual interviews when the data was saturated.

\section{Data Collection}

In the study, the data were collected through a semi-structured questionnaire using face-to-face interview method. The interviews were held between 5 July and 20 July 2020. After obtaining verbal consent from the participants who accepted to participate in the study, a suitable date and time were determined by the researchers, and interviews were made on the online medium. Before the interview, the research protocol was explained to the participants online. The interviews were made in a quiet and calm environment, with a tape recorder and necessary notes. In total, two interviews were conducted with each participant. In order to ensure that the study was conducted in a healthy and efficient manner, nurse academicians were also asked to convey their answers to study questions, their feelings, and thoughts about distance education in written form via e-mail.

\section{Instruments}

The data in the study were collected using a semi-structured interview form prepared by the researchers by scanning the literature (Sahu, 2020; Wang et al., 2020; Huang et al., 2020; Alamiah, Al-Khasawneh, \& Althunibat, 2020; Subedi, Nayaju, Subedi, Shah-Kumar, \& Shah-Mathias, 2020; Göktepe-Aydın, 2020; Serçemeli \& Kurnaz, 2020; Kürtüncü \& Kurt, 2020). The first part of the interview form, it is related to sociodemographic and distance education (age, gender, area of expertise, occupational study year, academic title, medina status, whether there is a child, where they live, how many people live at home, how they evaluate the use of technology, whether they have previous distance education experience). There are a total of 15 questions about whether distance education is beneficial for students, whether distance education is beneficial for students, whether or not to find the general course performance in distance education sufficient. In the second part of the interview form, nurse academicians 5 open-ended questions about distance education during the COVID-19 pandemic process (difficulties, achievements, coping methods for the difficulties experienced in the distance education process, what is done for personal and professional development in the distance education process, forward-looking anxiety and containing concerns) were asked. And these 5 open-ended questions consist of sub-questions that will enable them to express a little more (for distance education infrastructure, for face-to-face education, for lesson preparation, for use of technology, for questions and problems of students related to distance education, for the competence of providing distance education, for the time allocated for interviews; for academic studies, for saving time, for homework and examination system, for the decisions taken by universities regarding distance education; forward-looking solution suggestions, if any, and other sub-titles for them, if any).

\section{Data Analysis}

In the data analysis of this study, Colaizzi's seven-step descriptive phenomenological method was used. SPSS 24 package program was used in the analysis of the quantitative data part of the study. In the analysis of the qualitative data part of the study, the recorded voice recordings were listened to by the researchers over and over again and were compared with the written documents received via e-mail and combined in the computer environment. The documents transferred to the MAXQODA 11 software program were repeatedly read by the researchers, and the forms were given the code name S1, S2, $\mathrm{S} 3, \ldots, \mathrm{S} 18$. At the next stage, meaningful and relevant expressions were selected and categorized under certain themes. At the next stage, the findings were combined, and the findings and the actual experiences of nurse academicians on distance education were written in detail. The detailed descriptions were turned into short descriptions by the researchers. In the last stage, the researchers interviewed the participants again to verify whether the statements that were translated into writing included the real experiences of the participants regarding distance education.

\section{Validity and Reliability Studies}

In order to ensure reliability in phenomenological studies, participants are asked to read the written transcripts of the interview, express their opinions and confirm that their opinions are conveyed correctly, and this method is intended to provide internal validity and reliability (Guba \& Lincoln, 1994). In order to increase the consistency and reliability of the data, the researchers read the forms one by one with two experts and gave their opinions for each question. In phenomenological studies, reliability is evaluated as consensus / consensus and disagreement. Providing a consensus of $80 \%$ to the opinions expressed about the content of the answers given by the participants to the questionnaires is considered sufficient for reliability. In this study, it was determined that the questionnaire form was reliable by providing $100 \%$ consensus in the opinions of two experts and researchers regarding the question-answer content (Miles \& Huberman, 2015; Başkale, 2016).

\section{Ethical Consideration}

Ethics Committee approval was obtained from the Burdur Mehmet Akif Ersoy University Non-Interventional Clinical Research Ethics Committee before collecting the study data (Decision No: GO 2020/180); Written informed consent was obtained from the nurse academicians by confirming the participant form via verbal and e-mail. Assurance was given about the confidentiality of the information and sound recordings used in the study. In the study, instead of the name of the participants, the questionnaires were given code names as $\mathrm{S} 1, \mathrm{~S} 2, \mathrm{~S} 3$..., S18. This study was carried out taking into account the Good Clinical Practices and the Reporting Standards of Qualitative Researches of the Declaration of Helsinki. 


\section{RESULTS}

\section{Descriptive Results}

Table 1 demonstrated distributions of nurse academicians socio-demographic characteristics. It was seen that $64.7 \%$ of the participant academicians were aged between 41 and 47 years, $94.1 \%$ of them were female, $41.2 \%$ of them taught internal medicine nursing as their field of specialization, $41.2 \%$ of them had 5-10 years of professional experience, $76.5 \%$ of them possessed doctorate instructor as academic titles (Asst. Prof.), $52.9 \%$ of them were married and $52.9 \%$ of them resided in city centers (Table 1 ).

\section{Thematic Results}

As a result of the individual in-depth interviews with the nurse academicians, various sub-themes were determined in line with the five themes, "difficulties", "achievements", "coping methods', 'examination system' and 'views about the future'. Categories and themes resulted from interviews are given at Table 2.

\section{Theme 1: Difficulties encountered}

The theme "Difficulties encountered" was discussed under five sub-themes. These are "problems related to distance educa-

Table 1: Distribution of Nurse Academicians by Their Sociodemographic Characteristics

\begin{tabular}{|c|c|c|c|c|c|c|c|}
\hline Code & Age & Sex & Profession & $\begin{array}{l}\text { Years of work in } \\
\text { theprofession }\end{array}$ & Academic degree & Marital status & $\begin{array}{l}\text { Place of } \\
\text { residence }\end{array}$ \\
\hline S1 & 43 & $\mathrm{~F}$ & Internal Medicine Nursing & 20 & Assistant Professor & Married & District \\
\hline S2 & 45 & $\mathrm{~F}$ & Surgical Disease Nursing & 21 & Assistant Professor & Married & City \\
\hline S3 & 43 & $\mathrm{~F}$ & Internal Medicine Nursing & 20 & Assistant Professor & Single & City \\
\hline S4 & 43 & $\mathrm{~F}$ & Internal Medicine Nursing & 22 & Assistant Professor & Married & City \\
\hline S5 & 43 & $\mathrm{~F}$ & Surgical Disease Nursing & 18 & Assistant Professor & Married & District \\
\hline S6 & 41 & $\mathrm{~F}$ & Child Disease Nursing & 20 & Lecturer & Married & District \\
\hline S7 & 41 & $\mathrm{~F}$ & Internal Medicine Nursing & 22 & Assistant Professor & Single & District \\
\hline S8 & 32 & M & Internal Medicine Nursing & 6 & Lecturer & Married & District \\
\hline S9 & 42 & $\mathrm{~F}$ & Internal Medicine Nursing & 19 & Assistant Professor & Single & City \\
\hline S10 & 32 & $\mathrm{~F}$ & Internal Medicine Nursing & 9 & Assistant Professor & Single & City \\
\hline S11 & 41 & $\mathrm{~F}$ & Nursing Fundamentals & 5 & Lecturer & Married & City \\
\hline S12 & 31 & $\mathrm{~F}$ & Child Disease Nursing & 9 & Assistant Professor & Single & District \\
\hline S13 & 38 & $\mathrm{~F}$ & Obstetrics Nursing & 9 & Assistant Professor & Single & District \\
\hline S14 & 34 & $\mathrm{~F}$ & Public Health Nursing & 6 & Assistant Professor & Married & City \\
\hline S15 & 35 & $\mathrm{~F}$ & Child Disease Nursing & 12 & Assistant Professor & Single & District \\
\hline S16 & 44 & $\mathrm{~F}$ & Child Disease Nursing & 14 & Assistant Professor & Married & City \\
\hline S17 & 47 & $\mathrm{~F}$ & Public Health Nursing & 22 & Assistant Professor & Single & District \\
\hline S18 & 37 & $\mathrm{~F}$ & Internal Medicine Nursing & 18 & Assistant Professor & Single & City \\
\hline
\end{tabular}

Table 2: Category, Theme and Sub-Themes Obtained from the Interviews

\begin{tabular}{|c|c|c|}
\hline Category & Theme & Sub-themes \\
\hline & Difficulties encountered & $\begin{array}{l}\text { - Problems related to distance education infrastructure } \\
\text { - Restrictions of resources and loss of time } \\
\text { - Problems related to interactive education and interaction } \\
\text { - Course preparation and competence to teach the course } \\
\text { - Use of technology }\end{array}$ \\
\hline \multirow[t]{2}{*}{$\begin{array}{l}\text { Experiences of } \\
\text { nurse academicians }\end{array}$} & Distance Education Achievements & $\begin{array}{l}\text { - Academic studies and productivity } \\
\text { - Individual and professional development }\end{array}$ \\
\hline & $\begin{array}{l}\text { Coping Methods } \\
\text { Examination System } \\
\text { Views about the future }\end{array}$ & $\begin{array}{l}\text { - Positive coping methods } \\
\text { - Negative coping methods } \\
\text { - Academic assignments and grading } \\
\text { - Anxieties and worries }\end{array}$ \\
\hline
\end{tabular}


tion infrastructure", "restrictions of resources and loss of time", "problems related to interactive education and interaction", "course preparation and competence to teach the course", and "use of technology".

Sub-theme 1.1: Problems related to distance education infrastructure.

Identified problems related to distance education infrastructure were as follows: Nurse academicians had to record the videos again because there were infrastructural problems related to distance education preparations and thus distance education was initiated late. An intense and compressed study schedule was planned so that the course program could be completed in time according to the academic calendar. Academicians were unable to teach at times that they wanted to, they were unable to understand whether or not students were online, the internet connection was cut off and there were problems related to courses and videos. Some of the statements made were below:

- There were times when I could not log in to the system... I spent hours in front of the computer waiting to log in to the system...(S1), (S6), (S8), (S17)...I had to record the videos of courses again because the connection was often cut off. I had voice and image problems during the video recording... (S6)...Due to poor distance education infrastructure, it was an intense study program so that I could finish courses in time according to the academic calendar...(S5)

\section{Sub-theme 1.2: Restrictions of resources and loss of time}

Nurse academicians emphasized that they lost time since they were unable to provide a comfortable education setting by staying at home, there were difficulties such as computer and internet problems. They were alien to the distance education system, they were unable to re-prepare course notes according to the system and there were infrastructural deficiencies related to distance education.

- Because I did not have a satisfactory internet connection at home, I had to shuttle between work and home in order to record the courses and had to answer each student who listened to the course through recordings by using different technological methods (e-mail, WhatsApp, message, telephone); as a result of which I lost time ... since distance education was not a familiar system and technological infrastructure was poor; we had to spend more time...(S1), (S5), (S7), (S10), (S17)...It was impossible to launch live courses at home since I had children and I could not offer a comfortable educational setting...(S7), (S16)... Because my computer at home was an old one, it was charged during the course but even if I had a fast internet connection, it was sometimes cut off...(S15)

Sub-theme 1.3: Problems related to interactive education and interaction.

Nurse academicians said that they were unable to give an interactive education because students did not participate in theoretical courses actively, distance education was not suitable for clinical practice courses and internet connection was poor. Some of the statements were as follows:
- Most of the students joined courses via telephones... internet was cut off... Active participation in courses was impossible... it was not an interactive education...(S16)... For clinical practices, no interaction occurred in distance education, it was an unsuitable method and therefore, students fell behind in applied courses and had difficulties... (S4)... I had difficulties answering students' distance education problems and questions because I was unfamiliar with the system. Therefore; I directed the students to distance education administrators...(S1)

Sub-theme 1.4: Course preparation and competence to teach the course.

Nurse academicians expressed that they were not able to prepare course notes and alternative teaching techniques, arrange a quiet teaching/learning setting, and use the education materials due to time constraints. Some of the statements made were as follows:

- Course preparation was difficult for asynchronous courses... I had to wait for a quiet setting in order to record...(S10)... It was difficult to design alternative teaching techniques-particularly-for the applied courses so that the course could be a productive one...(S13)... The content was poor because we could not use each material (especially videos)...(S7)

\section{Sub-theme 1.5: Use of technology}

Nurse academicians pointed out that they experienced some problems related to getting used to distance education software technology and had difficulties uploading the courses to the system. Some of the statements were below:

- It was difficult to get used to distance education software technology that the university purchased... This technology should have been easier with simple steps...(S7)... I first had difficulties using this technology because distance education was a different system ...(S1)

\section{Theme 2: Distance Education Achievements}

Nurse academicians explained that distance education created more time in order to plan and conduct academic works and offered opportunities to write book chapters and articles. There were two sub-themes under Theme 2.

\section{Theme 2.1. Academic studies and productivity}

Nurse academicians emphasized that they had chances to work better, to plan new academic studies, and to write book chapters and articles. Some of the statements were below:

- Academically, I found a unique opportunity to work and to investigate better ... but practice and application processes were problematic...(S14)... I planned new academic studies in a shorter time...(S8)... My achievement about academic works during distance education was to write book chapters and articles....(S6)

\section{Theme 2.2. Individual and professional development}

Nurse academicians stated that they gained distance education experience, spared themselves extra time, and found more 
time for reading, watching, and joining online courses. Some of the statements were below:

- I gained teaching experience through distance education... (S5), (S6), (S7), (S13)... I found opportunities to join activities like courses, meetings, and seminars about distance education...(S9)... I read and watched a lot; which contributed to my individual development more...(S10)

Theme 3: Coping methods

Nurse academicians stated that they used such coping methods as utilizing distance education support system, re-preparing course presentations, increasing internet limits, participating in courses, meetings, seminars, solving problems by using telephones, e-mails, WhatsApp, and links, and crying, staying sleepless, and not being stressed. Two sub-themes were identified for this main theme:

\section{Theme 3.1. Positive coping methods}

Nurse academicians explained that they followed the distance education page, received assistance from distance education support assistants, joined activities like courses, meetings, seminars in order to solve problems, tried to be patient, and used various relaxation techniques like breath control. Some of the statements were as follows:

- During this process, I coped by using such methods as joining courses, lectures, meetings, seminars about distance education...(S9)... I tried to show patience by using technology more...(S10)... I coped by taking deep breaths and using breath control...(S5)

\section{Theme 3.2. Negative coping methods}

Nurse academicians explained that they cried, underwent stress, had to show tolerance, and suffered from sleeplessness problems in terms of distance education. Some of the statements were as follows:

- It was terrible to have to tolerate infrastructural deficiencies of the system... it caused me to have stress... I hoped that these hard times would pass and tried to do my best by trying to ignore and to close my eyes to deficiencies of the system...(S1)... I cried... I stayed awake at night due to course recordings and I slept in the day ... All my routines were ruined...(S6)

\section{Theme 4: Examination System}

Nurse academicians stated that there should be some restorations and improvements about academic assignments and examinations in relation to distance education. One sub-theme was discovered under the examination system.

\section{Theme 4.1. Academic assignments and grading}

Academic assignments and examinations failed to measure student success and achievements due to deficiencies in the system and there were some difficulties and security problems in applied courses. Some of the statements of the theme were as follows:
- We could not hold examinations properly and suitably through distance education... there were some security issues during the online examinations... as for the academic assignments, there were some question marks as to whether or not the assignments were done by the students themselves...(S7)... I think giving assignments and holding examinations via distance education does not help students... Particularly, for the applied courses...(S1), (S2)

Themes 5: Views about the future

According to the nurse academicians, their anxieties and worries were maximized about the future. One sub-theme was discovered under this theme.

\section{Sub-themes 5.1: Anxieties and worries}

It was noted that nurse academicians suffered from fears, stress, anxiety, and worry because of the idea that distance education and pandemic would last and the relevant problems would not be solved. Some of the statements of the theme were as follows:

- I was anxious about only teaching the applied courses... it is not a good situation that they would be inexperienced in the future when they were employed...(S14)... It was worrying for a student nurse to graduate via distance education without touching a patient...(S4)... It worried and made me anxious that students would be graduating from schools that taught applied for courses without experiencing a real patient and clinical setting (medicine, nursing, physical therapy, etc)...(S2)

\section{DISCUSSION}

Distance education is not a novel platform for many universities over the world but the COVID-19 outbreak required emergent planning and made distance education essential for universities without infrastructure or with insufficient infrastructure. During the pandemic, connecting globally to the internet at the same time and forcing preexisting infrastructure conditions due to the distance education made distance education system complicated both for the educators and students (Sahu, 2020; Wang et al., 2020).

In the literature, educators who teach applied courses emphasize that a hasty and unprepared transition to the COVID-19 pandemic affected education negatively. The reasons of which can be listed as lack of mutual interaction and communication between teachers and students, inefficient teaching hours, inability to give theoretical and practical courses together and poor e-learning opportunities for teachers to interact with students (Sintema, 2020; Serçemeli \& Kurnaz, 2020). In the literature; $40.6 \%$ of the academicians put an emphasis on the fact that they had problems with universities' distance education infrastructures, their internet access was problematic (Serçemeli \& Kurnaz, 2020), their opportunities were limited, they were not pleased that education was not face-to-face. They were worried about how the applied courses would be taught and how examinations and examination assessment would be, they experienced difficulties with public transpor- 
tation and internet connection since they lived in rural areas (Kartepe, Küçükgençay, \& Peker, 2020). They did not have enough internet and computers due to economic difficulties. They were psychologically and negatively affected due to pandemic and they were scared and anxious that they would contract the disease (Kürtüncü \& Kurt, 2020; Sahu, 2020; Wang, Di, Ye, \& Wei, 2020; Huang et al., 2020). In this study, too, it was noted that theoretical courses generally had to be given asynchronously due to insufficient distance education infrastructure whereas applied courses had to be given synchronously. Academicians argued that particularly applied courses cannot be taught asynchronously but if distance education will be continued, infrastructural problems have to be solved and these courses should be offered synchronously. These results point out that distance education does not answer to needs of applied sciences, education institutions should correct deficiencies in the distance education system in cases of state of emergency such as natural disasters and pandemics so that these institutions can be synchronized and it is understood. It is important to make academicians who give distance education receive relevant on-job-trainings about distance education, technology, and internet use. It is seen that distance education is an optional model to be used to balance work and life rather than an obligatory model. In the COVID-19 pandemic period, social isolation is necessary to protect people's health and to impose sanctions; which has made distance education, not an option but an obligation (Göktepe Aydın, 2020).

In this study towards the difficulties encountered; it was reported that nurse academicians were not ready and prepared for the distance education system, had difficulties with teaching theoretical and practical courses through distance education due to infrastructural complications, did not have sufficient technological equipment's to work at home and experienced internet connection problems. Similar to our study findings, the study suggested that academicians expressed negative opinions about technical infrastructure problems and did not have sufficient equipment and technical knowledge to work at home (Göktepe Aydın, 2020). When the literature is looked at; academicians' preparedness, experiences, specialization in distance education are important in maximizing educational success (Alea-Aris et al., 2020; Koloğlu, Kantar, \& Doğan, 2020; Özgöl, Sarikaya, \& Öztürk, 2017; Yıldız \& Selim, 2015). Insufficient facilities, equipment's and capacity building in distance education are reported to be significant barriers for teachers to provide distance education. It is important in maximizing academic performance to allow time for an academician to prepare for distance education, to offer them training about the distance education system so that their knowledge and skills of distance education can be improved, and to provide institutions with educational sets (Alea-Aris et al., 2020; Fatmasari, 2018). It is seen in literature that there are results similar to our study findings indicating that academicians' work burden increases during course-preparation, preparing course notes makes them lose time (Özgöl et al., 2017). Since time is limited course notes are carelessly and hastily prepared; which influences the quality of courses negatively (Yıldız \& Selim, 2015). Time is not enough in the distance education system; which limits teaching academic subjects and discussing case studies (Serçemeli \& Kurnaz, 2020). When the literature is examined, it is noted that -similar to the findings of the current studyinternet disconnection or students' internet disconnection during teaching disturbs teachers, distracts their attention, and experiencing such problems as infrastructural deficiencies (Alamiah et al., 2020; Subedi et al., 2020) influences education negatively (Özgöl et al., 2017; Yıldız \& Selim, 2015; llgaz, 2014). Considering the results of the current study; it is significant to make necessary and relevant arrangements and corrections so that academicians can be provided with technical type of equipment and necessary training about distance education, computer, and the internet, to update and to increase their technical knowledge and to give them virtual training.

In this study, nurse academicians emphasized that they gained distance education experience as distance education achievements during the COVID-19 pandemic in terms of individual and professional development, and they had the chance to participate in plenty of reading, online meetings, seminars, and on-the-job courses. When the literature was investigated, it was identified that results similar to our study findings were seen and that -by teaching through distance education and working at home- the participating academicians saved time (Göktepe Aydın, 2020; Subedi et al., 2020; Özgöl et al., 2017). It has been determined that they spend more time for academic studies and academic activities (writing books, writing articles, etc), for domestic responsibilities (cooking, cleaning), for domestic roles (raising up children) (Göktepe Aydın, 2020; Subedi et al., 2020), for hobbies (watching TV, listening to music, spending time on hobbies) (Göktepe Aydın, 2020; Kaya, Akyol Çitil, Özbek, \& Pepeler, 2020) ). It has been determined that they used internet sources more effectively for their academic fields; improved their professional developments; adapted to up-to-date technologies and teaching tools more easily (Serçemeli \& Kurnaz, 2020; Özgöl et al., 2017); had more opportunities for new and novel ideas (Abazoğlu, Yatağan, Arifoğlu, \& Umurhan, 2015) ). It has been determined that they had their professional and individual developments influenced positively; discovered different programs; got tired less and communicated with students on different platforms (Bakioğlu \& Çevik, 2020). These outcomes made us conclude that transition to distance education system during pandemic contributed to academicians' academic studies and increased their productivity and helped their professional and individual development.

In the current study; nurse academicians emphasized that as coping methods, they built positive and negative coping methods in relation to distance education and the COVID-19 pandemic. When the literature was looked at, results similar to our study findings were found and the academicians emphasized the need for support in computer and internet in order to eliminate negative feelings, had to deal with work and home responsibilities together and felt useless and worthless (Göktepe Aydın 2020). As negative attitudes, teachers explained that school life was stressful and distance education challenged them and as a result, felt scared and empty (Bakioğlu \& Çevik, 2020; Göktepe Aydın 2020). 
Of the ideas about the examination system, the participant nurse academicians reported that assignment and grading systems should be changed and improved, online assignments, and examination systems were not capable of measuring student success and there were security fears in online assignments and examinations. When the literature was looked at, there were results that concurred with our study findings and the academicians argued that teaching with distance education decreased academic success, examination should be done face to face (Koloğlu et al., 2020; Özgöl et al., 2017). It is stated that a real measurement and evaluation cannot be made in distance education, and advanced skills cannot be measured and evaluated (Koç, 2020; Kurnaz and Serçemeli, 2020). These results of the studies made us conclude that strengthening the examination and academic assignment infrastructure of distance education will influence academic success and achievement and assessment and evaluation positively.

Nurse academicians views about the future, they stated that if the problems and difficulties are not eliminated and solved; their level of anxiety, worry, and stress may increase. When the literature was looked at, results similar to our study findings were found and the studies done with academicians suggested that they suffered from anxiety during a pandemic and preferred to spend more time working in order to decrease their anxiety (Göktepe Aydın, 2020). Studies done with teachers reported that -during the COVID-19 pandemic- they were worried due to such reasons like lack of knowledge, being unhappy, feeling of inability, and feeling that they could not reach the students (Bakioğlu \& Çevik, 2020). Thinking of situations like staying at home, family health and security, work status, family income, internet, and electricity cut-off, and inability to answer students' questions doubled their anxiety of teachers (Wang et al., 2020; Subedi et al., 2020). These results proved to us that anxiety and mood disorders caused by the pandemic and distance education should be explored and necessary educational and psychological counseling services should be provided in order to eliminate these disorders and relevant deficiencies.

\section{Study's Limitations}

The limitations of this study are that the authors and participants experienced various interruptions due to internet access during online interviews. For this reason, some interviews had to be repeated. Second, in the study, more nurse academicians were wanted to be reached, but 18 nurse academicians were reached due to their hard work and being in the summer vacation period. Therefore, the findings obtained are limited only to the views of the 18 nurse academicians who participated in the study.

\section{CONCLUSION and RECOMMENDATIONS}

In a conclusion; it was identified that nurse academicians did not have any distance education experiences, got caught unprepared in distance education, had difficulties with course preparation, technology use, answering students' questions and problems, wasted time in the course preparation phase, gained some achievements in academic. Nurse academicians developed productivity, personal and professional development, positive and negative coping methods, gained experience and felt anxiety about the future. The universities where they worked had the insufficient infrastructure and limited resources, and interactive education was not possible. Following on from these results; it is recommended that because distance education failed in applied courses; different solutions should be found and distance education infrastructure deficiencies should be corrected, necessary on-job training and educations should be provided to academicians and students about distance education. Universities' distance education infrastructure should be improved and updated; resources in the internet, transportation, computer use should be extended; applied courses should be postponed as much as possible and revised in the next academic year through accelerated education programs. Nurse academicians should complete academic preparations for applied and theoretical courses during distance education and develop new strategies and psychological support units that should be established for nurse academicians against stressful and worrying situations.

\section{Implications for Nursing Education}

It is nurse academicians and nursing students who have the biggest and most frequent difficulties with distance education in health sciences during the COVID-19 pandemic. Nurse academicians hasty transition to distance education and ambiguity caused by the process have caused unfamiliarity with distance education and the fear of complex distance education caused by stress, anxiety, and the COVID-19 contamination (learning and teaching processes). However, it is also understood that academicians considered the pandemic period and distance education as an opportunity for their academic studies, saved time, and studied better in their academic works.

In sum, we are of the opinion that taking academicians' views about distance education will help other academicians improve their skills, will enable course curriculums to be restructured better, will eliminate distance education infrastructure deficiencies, and will guide for future academic studies.

\section{Declaration of Conflicting Interests}

The authors declared no potential conflicts of interest with respect to the research, authorship, and/or publication of this article.

\section{Financial Disclosure}

This research did not receive any specific grant from funding agencies in the public, commercial, or not-for-profit sectors.

\section{REFERENCES}

Abazoğlu, ì., Yatağan, M., Arifoğlu, A., \& Umurhan, H (2015). Students' mathematics achievement trends of the international science and mathematics evaluation of research results. International Periodical for the Languages, Literature and History of Turkish or Turkie, 10(7), 33-50.

Akca, M., \& Tepe Kücükoğlu, M (2020). COVID-19 and its effects on business life: Work at home. Journal of International Management, Educational and Economics Perspectives, 8(1), 71-81. 
Almaiah, MA., Al-Khasawneh, A., \& Althunibat, A (2020). Exploring the critical challenges and factors influencing the e-learning system usage during COVID-19 pandemic. Education and Information Technologies, 1-20. https://doi.org/10.1007/s10639020-10219-y.

Alea-Aris, L., Fabrea-Frosyl, M., Roldan-Artur, DR., \& Farooqi, ZA (2020). Teachers' COVID-19 awareness, distance learning education experiences and perceptions towards institutional readiness and challenges. International Journal of Learning, Teaching and Educational Research, 19(6), 127-144. https:// doi.org/10.26803/ijlter.19.6.8.

An, P., Song, P., Lian, K., \& Wang, Y (2020). CT manifestations of novel coronavirus pneumonia: A case report. Balkan Medical Journal, 37, 163-5. https://doi. org/10.4274/balkanmedj.galenos.2020.2020.2.15.

Aslan, R (2020). Endemic diseases in history and today and COVID-19. Ayrınt Journal, 8(85), 35-41.

Bakioğlu, B., \& Çevik, M (2020). Science teachers' views on distance education in the COVID-19 pandemic process. Turkish Studies, 15(4), 109-129. https://doi.org/10.7827/TurkishStudies.43502.

Başkale, H (2016). Determination of validity, reliability and sample size in qualitative studies. Dokuz Eylul University E-Journal of Nursing Faculty, 9(1), 23-28.

Council of Higher Education (CHE) (2020a). Press briefing. https:// www.yok.gov.tr. Accessed 7 September 2020.

Council of Higher Education (CHE) (2020b). Press briefing. https:// www.yok.gov.tr. Accessed 7 September 2020.

Council of Higher Education (CHE) (2020c). Press briefing. https:// www.yok.gov.tr. Accessed 7 September 2020.

Dockery, M., \& Bawa, S (2020). Working from Home in the COVID-19 Lockdown. Bankwest Curtin Economics Centre Research Brief COVID-19, 1-5. https://bcec.edu.au/assets/2020/05/BCECCOVID19-Brief-4_Working-from-home.pdf Accessed 1 October 2020.

Fatmasari, R (2018). Teaching practice in distance education context. SHS Web of Conferences 42(2), 00099. https://doi. org/10.1051/shsconf/20184200099.

Göktepe Aydın, E. (2020). A phenomenological research to determine Individuals' perception of distance (work from home) model in pandemic period; Public university example. Journal of Current Researches on Business and Economics, 10(1), 29-42. https://doi.org/10.26579/jocrebe.68.

Guba, EG., \& Lincoln, YS (1994). Competing paradigms in qualitative research. In. N. K. Denzin, \& Y.S. Lincoln (Eds.), Handbook of qualitative research. (pp. 105-117). Thousand Oaks, CA: Sage.

Honey-Roses, J., Anguelovski, I., Bohigas, J., Chireh, V., Daher, C., Konijnendijk, C.,.....\& Nieuwenhuijsen, M (2020). The impact of COVID-19 on public space: A review of the emerging questions. https://doi.org/10.31219/osf.io/rf7xa.

Huang, C., Wang, Y., Li, X., Ren, L., Zhao, J., Hu, Y. I., ... \& Cao, B (2020). Clinical features of patients infected with 2019 novel coronavirus in Wuhan, China. The Lancet, 395(10223), 497506. https://doi. org/10.1016/S0140-6736(20)30183-5.

Ilgaz, H (2014). The problems of distance education students on synchronized learning applications and suggestions for solutions. Educational Sciences and Practice Journal, 13(26), 187-204.
Joseph, ML (2007). Innovativeness in nursing: A phenomenological and constructivist study. Doctoral Thesis, Capella University: Minneapolis.

Kartepe, F., Küçükgençay, N., \& Peker, B (2020). What are the perspectives of teacher candidates on synchronous distance education? A survey study. Journal of Social and Humanities Sciences Research. 7(53), 1262-1274. http://dx.doi. org/10.26450/jshsr.1868.

Kaya, M., Akyol Çitil, C., Özbek, R., \& Pepeler, E (2017). Views of academicians in 'department of educational sciences' about 'distance education application' at post-graduate education programs. Electronic Journal of Social Sciences, 16(64), 16161627.

Kissler, S. M., Tedijanto, C., Goldstein, E., Grad, YH, \& Lipsitch, M (2020). Projecting the transmission dynamic of SARS-CoV-2 through the postpandemic period. Science, 368(6493), 860868. https://doi.org/10.1126/ science.abb5793.

Koç, E (2020). An evaluation of distance learning in higher education through the eyes of course instructors. Akdeniz Journal of Education, 3(1), 25-39.

Koloğlu, FT., Kantar, M., \& Doğan, M (2016). The importance of lecturers' readiness in distance education. Journal of Açıöğretim Applications and Research, 2(1), 52-70.

Kürtüncü, M., \& Kurt, A (2020). Problems of nursing students in distance education in the COVID-19 pandemia period. Eurasian Journal of Researches in Social and Economics, 7(5), 66-77.

Lu, H., Stratton, CW., \& Tang, YW (2020). Outbreak of pneumonia of unknown etiology in Wuhan, China: The mystery and the miracle. Journal of Medical Virology, 92, 401-402. https://doi. org/10.1002/jmv.25678.

Miles, MB., \& Huberman, AM (2015). Nitel veri analizi. In. A. S., Altun \& A., Ersoy (Eds.) (pp. 10-317). Ankara: Pegem A Yayıncılık.

Özgöl, M., Sarikaya, İ., \& Öztürk, M. (2017). Students' and teaching staff's assessments regarding distance education applications in formal education. Journal of Higher Education and Science, 7(2), 294-304. https://doi.org/10.5961/jhes.2017.208.

Sahu, P (2020). Closure of universities due to coronavirus disease 2019 (COVID-19): Impact on education and mental health of students and academic staff. Cureus, 12(4), e7541. https://doi. org/10.7759/cureus.7541.

Serçemeli, M., \& Kurnaz, E (2020). A research on students' perspectives to distance education and distance accounting education in the COVID-19 pandemia period. International Journal of Social Sciences Academic Researches, 3(3), 2687-2641.

Sintema, JE (2020). Effect of COVID-19 on the performance of grade 12 students: Implications for STEM education. EURASIA Journal of Mathematics, Science and Technology Education, 16(7), 1-6. https://doi.org/10.29333/ejmste/7893.

Subedi, S., Nayaju, S., Subedi, S., Shah-Kumar, S., \& Shah -Mathias, J (2020). Impact of e-learning during COVID-19 pandemic among nursing students and teachers of Nepal. International Journal of Science and Healthcare Research, 5(3), 68-76.

Telli, YS., \& Altun, D (2020). The coronavirus and the rising of online education. Journal of University Research, 3(1), 25-34. https://doi.org/10.32329/uad.711110. 
The United Nations Children's Fund (UNICEF). UNICEF and Microsoft launch global learning platform to help address COVID-19 education crisis. (2020). https://www.unicef.org/press-releases/unicefand-microsoft-launch-global-learning-platform-help-address-covid-19-education. Accessed 1 October 2020.

Turkish Ministry of Health (TMH). COVID-19 information page (2021). https://covid19.saglik.gov.tr/ Accessed 2 July 2021.

Viner, MR., Russell, S., Croker, H., Packer, J., Ward, J., Stansfield, C., .....\& Booy, R (2020). School closure and management practices during coronavirus outbreaks including COVID-19: A rapid systematic review. The Lancet Child \& Adolescent Health, 4, 397-404. https://doi.org/10.1016/ S2352-4642(20)30095-X.

Wang, C., Cheng, Z., Yue, XG., \& McAleer, M (2020). Risk management of COVID-19 by universities in China. Journal of Risk and Financial Management, 13(36), 1-6. https://doi. org/10.3390/ jrfm13020036.
Wang, Y., Di, Y., Ye, J., \& Wei, W (2020). Study on the public psychological states and its related factors during the outbreak of coronavirus disease 2019 (COVID-19) in some regions of China. Psychology, Health \& Medicine. http://dx.doi.org/10.1 080/13548506.2020.1746817.

World Health Organization (WHO). WHO Coronavirus (COVID-19) Dashboard (2021). https://covid19.who.int/ Accessed 2 July 2021.

Yıldız, M., \& Selim, Y (2015). A qualitative study on transferring the experience of using technology from formal education to distance education. Turkish Online Journal of Distance Education, $16(4), 125-134$ 